\title{
Nursing work in assisted human reproduction: between technology and humanization
}

\author{
Trabalho do enfermeiro em reprodução humana assistida: entre tecnologia e humanização \\ El trabajo del enfermero en reproducción humana asistida: entre la tecnología y la humanización
}

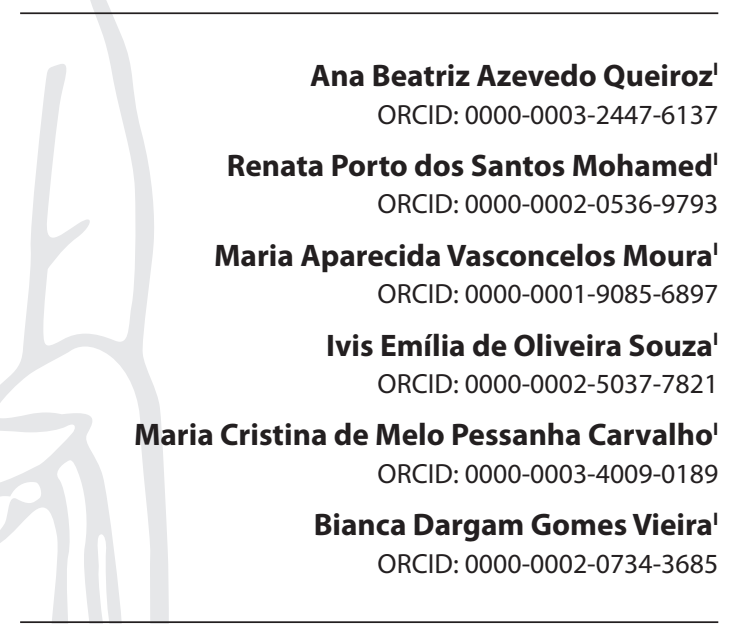

' Universidade Federal do Rio de Janeiro. Rio de Janeiro, Rio de Janeiro, Brazil.

How to cite this article: Queiroz ABA, Mohamed RPS, Moura MAV, Souza IEO, Carvalho MCMP, Vieira BDG. Nursing work in assisted human reproduction: between technology and humanization. Rev Bras Enferm. 2020;73(3):e20170919. doi: http://dx.doi.org/10.1590/0034-7167-2017-0919

Corresponding author: Ana Beatriz Azevedo Queiroz E-mail: abaqueiroz@hotmail.com

EDITOR IN CHIEF: Dulce Aparecida Barbosa ASSOCIATE EDITOR: Margarida Vieira

Submission: 01-11-2018 Approval: 02-19-2019

\begin{abstract}
Objectives: To analyze the social representations of nurses who work with assisted human reproduction about the operation with reproductive biotechnologies. Methods: Qualitative approach, supported by the Theory of Social Representations, with sixteen participants. Individual, semi-structured interviews, analyzed through the Alceste software. Results: Pragmatic elements related to nurses' performance from a professional, institutional, and public policy perspective in reproductive biotechnologies emerged, demonstrating the practical dimension of these representations. The characteristics of the professional to act in this area were addressed, showing the lack of information and search for scientificity; precarious perception of the organizational structure of health services; and attributions of nursing care arising from the health care practice in assisted human reproduction. Final considerations: Social representation is anchored in the link between technology/medicalization and humanization/reception regarding reproductive biotechnologies. Working in assisted human reproduction involves a new and challenging nursing care, requiring specific and ethical knowledge.

Descriptors: Nursing; Reproductive Health; Reproductive Techniques; Humanization of Assistance; Psychology, Social.
\end{abstract}

\section{RESUMO}

Objetivos: Analisar as representações sociais do enfermeiro que trabalha com reprodução humana assistida acerca da atuação com biotecnologias reprodutivas. Métodos: Abordagem qualitativa sustentada pela Teoria das Representações Sociais com dezesseis participantes. Entrevista individual, semiestruturada, analisada pelo software Alceste. Resultados: Emergiram elementos pragmáticos relacionados à atuação do enfermeiro na perspectiva profissional, institucional e de conformação das políticas públicas em biotecnologias reprodutivas, demonstrando a dimensão prática dessas representações. Abordaram-se as características do profissional para atuar nesta área, demonstrando carência de informação e busca pela cientificidade; percepção precária da estrutura organizacional dos serviços de saúde; e atribuições do cuidado do enfermeiro que advêm da prática assistencial em reprodução humana assistida. Considerações finais: A representação social ancora-se no elo entre a tecnologia/medicalização e a humanização/acolhimento em relação às biotecnologias reprodutivas. $\mathrm{O}$ trabalho em reprodução humana assistida envolve um novo e desafiador cuidado de enfermagem e exige conhecimento específico e ético.

Descritores: Enfermagem; Saúde Reprodutiva; Técnicas Reprodutivas; Humanização da Assistência; Psicologia Social.

\section{RESUMEN}

Objetivos: Analizar las representaciones sociales del enfermero que trabaja con reproducción humana asistida acerca del trabajo con biotecnologías reproductivas. Métodos: Estudio de tipo cualitativo basándose en la Teoría de las Representaciones Sociales, realizado con 16 participantes. Las entrevistas individuales, semiestructuradas, se analizaron por medio del software Alceste. Resultados: Se desvelaron los elementos pragmáticos relacionados al desempeño del enfermero desde la perspectiva profesional, institucional y de conformación de las políticas públicas en biotecnologías reproductivas, demostrando la dimensión práctica de esas representaciones. Se abordaron las características del profesional para actuar en este campo, demostrando carencia de información y búsqueda del valor científico; la percepción precaria de la estructura organizativa de los servicios de salud; y las funciones del cuidado del enfermero provenientes de la práctica asistencial en reproducción humana asistida. Consideraciones finales: La representación social se fundamenta en el enlace entre la tecnología/medicalización y la humanización/acogida con relación a las biotecnologías reproductivas. El trabajo en reproducción humana asistida implica un nuevo y desafiante cuidado de la enfermería y le exige un conocimiento específico y de la ética.

Descriptores: Enfermería; Salud Reproductiva; Técnicas Reproductivas; Humanización de la Atención; Psicología Social. 


\section{INTRODUCTION}

Assisted human reproduction (AHR) comprises a set of biotechnological interventions on the human reproductive process, which has been widely used in developed countries. In the Brazilian context, the technique has been growing under the technical-scientific domain of the private sphere, albeit it bashfully presents itself in some public instances, mostly linked to university institutions (1). $^{(1)}$.

Reproductive biotechnology that transforms human reproduction into a new perspective on procreation science arises as a result of social transformations and profound changes in human relations, often mediated by great technological and scientific advances. It is innovation that materializes through a set of techniques of the biomedical universe, such as artificial insemination and in vitro fertilization ${ }^{(2)}$.

Initially, the AHR was developed to promote pregnancy in cases of reproductive difficulty diagnosed as infertility. Nowadays, however, it meets the demands of reproduction of celibatarians, serodiscordant couples for the Human Immunodeficiency Virus (HIV), homoaffective relationships, or in late motherhood ${ }^{(3)}$.

To understand the contemporary construction of AHR, one needs to broaden the understanding on demands for reproductive biotechnologies, based mainly on the social and cultural importance of the family/parental constitution intermediated by the biological child, as a consequence of a reproductive dream ${ }^{(3)}$.

Fertility and reproduction have always been human concerns, especially regarding the importance given to the perpetuation of family lineage through the parents' genetic material (offspring) and the representative elements of the biological child, as structural elements for the personal fulfillment of both men and women ${ }^{(4)}$.

Reproductive biotechnologies are embedded in a plurality of biological body conditions that inevitably lead to numerous dilemmas, especially face the AHR-related issues such as artificial insemination, in vitro fertilization, replacement uterus, cloning, stem cells, and cryopreservation of gametes/embryos. Insofar as it approaches people's daily life, it fosters discussions and questions that return to society, embodied by market issues or scientific or fictional media ${ }^{(5)}$.

The AHR expansion is close to the daily routine of nurses working in the areas of sexual and reproductive health of couples/ individuals, both in primary health care settings and in those specialized in human reproduction. Throughout the social practice of these nurses, information and conversations circulate that, through logical and coherent mechanisms, lead to the articulation of positions and attitudes related to assistance/care to couples/ individuals who seek these biotechnological interventions.

The law on nursing professional practice, regulated by Decree No. 94,406/1987, attributes to the nurse, as a professional member of the health team, the performance in the obstetric and reproductive area, considering its technical complexity and the scientific knowledge necessary to proper act in decision-making ${ }^{(6)}$.

Given that, one could perceive in the practice routine a diversity of AHR meanings produced by nurses, who end up directing their work towards these technologies. These practices are built from the psycho-sociological perspective of interactions between people, professionals and environments ${ }^{(7)}$, and ought be investigated considering the Theory of Social Representations (TRS), in which the knowledge about an object has a strong connection with the actions of the subjects ${ }^{(8)}$.

Therefore, this study aims to understand how and what this social group thinks about AHR-related issues, and how the construction of these social representations has repercussions on the position of this professional before the couple/individual who seeks the new reproductive biotechnologies. Representations are the fruit of the interaction between individuals integrated in certain cultures that, at the same time, construct and produce an individual history and also a social history ${ }^{(9)}$.

The information and contents of the biotechnological revolution in AHR are subject to a re-signification by the nurses working in the area of sexual and reproductive health, who confront personal values with those acquired in the professional routine, with imnplications on their way of assisting and caring for couples/individuals seeking these technologies.

In addition to nurses' familiarization with technical and scientific knowledge about AHR, these modes require the organization of these knowledge in a necessary alignment with subjectivities, such as affection, interest, and motivation, as they are interwoven by the psychosocial issues of the context in which they are inserted.

\section{OBJECTIVE}

To analyze the social representations of nurses working with AHR about their work with reproductive biotechnologies.

\section{METHOD}

\section{Ethical aspects}

The ethical principles contained in the National Health Council Resolution No. 466/2012 $2^{(10)}$, regarding research involving human beings, were respected, and the project was approved by the Research Ethics Committee of the Anna Nery School of Nursing and the São Francisco de Assis Institute of Health Care of the Federal University of Rio de Janeiro. Participants signed the Free and Informed Consent Form and, to preserve their anonymity, the nomenclatures $(P)$ were used for participants, followed by $(M)$ for male or (F) for female, and the respective ordinal number for the participant interviews (for example, P.F.1, P.M.2, P.M.16 etc.).

\section{Theoretical-methodological framework and type of study}

This is an exploratory research with a qualitative and descriptive approach, developed by the application of the Theory of Social Representations in its procedural approach. In this directive, it is based on the assumption that participants' social practices expose a non-visible reality, due to motives, aspirations, values, beliefs and attitudes that permeate the subjects' subjectivity ${ }^{(7)}$. The TRS, as a theoretical and methodological foundation, made it possible to unveil the nurses' thinking references about AHR, through psychosocial elements that support the way in which these professionals act in relation to reproductive biotechnologies in their professional life. 


\section{Methodological procedures, study scenario, and data sources}

Sixteen nurses who worked in the area of sexual and reproductive health in the city of Rio de Janeiro participated in the study. As inclusion criterion, were considered nurses who worked with AHR for at least one year. This time of practice in the area was stipulated due to being understood as a reasonable period of professional practice so that the participants were able to convert this experience in the construction of social representations about the object.

Recruitment occurred through the snowball sampling technique , favoring the non-random acquisition of new participants, successively, until data saturation. Such technique is usually indicated for a highly specialized population with a small number of members ${ }^{(11)}$, as is the case of nurses working with AHR in Rio de Janeiro.

The initial field of study was a university public health unit that provides care to individuals/couples living in an infertility situation. This health institution with attention to human reproduction was the driving force for the initial recruitment of participants who, upon request, indicated new possible professionals working in these services, both in public and private instances, using their own interpersonal connections network.

New participants were carefully contacted, avoiding nuisances in their professional and/or personal routines. At the opportunity they were asked about the desire to participate in the research, after reading and explaining the study objectives. Upon agreement, the data collection took place according to the availability of time and place chosen by the participants.

\section{Data collection and organization}

The in-depth interview technique was approached individually and occurred between May 2014 and January 2015, through the signing of the Informed Consent Form. Interviews were based on a semistructured script with objective questions, to delineate the demographic, socioeconomic and academic profile, and open questions, so to explore nurses' meanings regarding their performance in assisted human reproduction. They were recorded in MP3 and transcribed in full, and then carefully read to begin the analysis of these results.

\section{Data analysis}

Results were analyzed using the Alceste software (Analyse Lexicale par Contexte d'un Ensemble de Segments de Texte), allowing to distinguish classes of words that represent different forms of discourse of a thematic, whose base of operation resides in the idea that lexical worlds can only be understood in a larger scheme of relations by contrast or complementarity ${ }^{(12)}$. From the textual organization, there were successive divisions of the corpus, observed through the descending hierarchical classification, allowing to identify the most evident oppositions between the words of the text and to create the conditions to extract the representative classes to be analyzed. The corpus was formed by initial context units (ICU), which correspond to the sixteen interviews.

After running it, Alceste segmented the texts into units of elementary contexts (UEC), which correspond to the discursive material by the significant lexicons that are at the origin of class formatting. Alceste totaled $75 \%$ of use of the analyzed corpus, giving rise to six thematic classes. The analysis of the most significant lexicons and their association with the UEC of each class allowed understanding the meanings and images emerging from the participants' discourse. Thus, classes 1,5 and 6 presented contents related to the nurses' performance in AHR, which is the object of this study, grouping 258 UCE that corresponded to $51 \%$ of the corpus.

Class 1 was named "Nurses and assisted human reproduction: characteristics of the professional who works in this area"; class 5 , "Structure of health services in assisted human reproduction"; and class 6, "Assignments of nurse practice/care in assisted human reproduction, anchored between technology and humanization". The data produced were analyzed by Theory of Social Representations.

\section{RESULTS}

The demographic, socioeconomic and academic profile of the 16 interviewees showed that 12 (75\%) were female; 9 (56\%) were in the age group between 26 and 45 years old; 10 (63\%) declared themselves to be white; 13 (81\%), Catholics; and 11 (69\%), married with children. Academic, professional and economic data resulted in 12 (75\%) with more than 15 years of training and 16 (100\%) with lato sensu graduation, and for 15 (94\%) of them the specialization was outside the area of sexual and reproductive health, and $13(81 \%)$ stated they had no contact with the AHR theme during undergraduation. The individual income of 11 (69\%) participants was above 8 minimum salaries, of which 8 (50\%) reported having two employment relationships. The internet and the work environment were the sources of information about AHR most mentioned by the research participants.

\section{Class 1: Nurses and assisted human reproduction: charac- teristics of the professional working in this area}

Class 1 presented 143 UEC, representing 28\% of the corpus. By the most frequent terms and typical UEC of this class, one can infer that the contents are grouped around the relation between the nurse and the AHR. Three sub-themes were identified, demonstrating this relation: lack of information and search for scientificity; assistance practice as training; and figure-type nurses working in assisted reproduction.

Lexicals such as"knowledge","lack","little","'college","specialize" and "information" reveal the dimension of AHR information for nurses working with reproductive biotechnologies. The UEC contents showed the lack of protocol and formal information about the AHR in nursing education institutions, expressed by the sixteen interviewees.

Regarding assisted reproduction, colleges do not address this topic, we arrive here withno information whatsoever, no knowledge at all.(P.F.16)

Saying you are against assisted reproduction and turning your back on it is worthless. Much of what the nursing college and our council should create, address, and teach as a academic subject or even a specialization is lacking. (P.M.13)

As a strategy to fill this gap of formal knowledge in the academy, twelve of the participants used an individual/personal search with participation in congresses and, mainly, through 
the internet, through access to manuals, specialized websites and scientific articles in the specific area.

I always try to study through internet, articles and books. I search the team I work [with] to dispel my doubts. That's how l learn to work in assisted reproduction. We must go after it by ourselves. (P.M.15)

I'm always reading on the subject, I'm an associate of the Brazilian Society of Assisted Reproduction and I receive the journals, which help alot; and, of course, the internet, through specialized websites. (P.M.1)

In this informational dimension of the TRS, the professional practice and care routine in the AHR were pointed out as producers of knowledge, enabling them to work in the area, being the great enabler.

We learn from the work routine, we kind of specialize ourselves by hook or crook, in practice, in our daily living. (P.M.13)

My knowledge on assisted reproduction came from work. When I came to work here I knew nothing. I learn at work and in care. What really trained me was daily practice. (P.F.14)

In this context, through the search for information and knowledge, the participants described the characteristics of a good nurse to work in the AHR area. The nurses considered compatible with the environment of reproductive biotechnology professionals who present characteristics related to the academic universe, such as being studious, ethical and welcoming, and especially dedicated and exclusive.

It's not just any nurse who knows how to work in this area. There is no point in having specialization in the area of women or in obstetrics! Here one must go after it, seek knowledge, get involved, unless they want to be merely a bureaucratic nurse, with no knowledge or professional upgrading. A good nurse in assisted human reproduction must be above all welcoming, attentive and up-to-date. (P.F.14)

First of all, I think they must be a good nurse, committed and responsible, but to work in assisted production one must have encouragement and motivation. One must be above all respectful and ethical. The issue of secrecy must also be preserved because this issue of assisted reproduction is a polemic theme that involves sexuality, infertility, which are full of social stereotypes. (P.F.8)

In this perspective of practice restructuring and new challenges, by engaging with an area that is still little known and explored by nursing the participants demonstrated satisfaction in the daily work with the AHR, according to their testimonies:

I embraced it very intently, I felt much identification with assisted reproduction, I guess I have find myself in it. I like to interact, to give, to exchange; I'm helping couples to fulfill theirdream of having a child. (P.F.3)

Working with assisted human reproduction is a new thing, it is intriguing and of great importance in the context of infertility. (P.M.12)

\section{Class 5: Structure of health services in assisted human reproduction}

Class 5 was composed of 74 UEC, representing $15 \%$ of the corpus. This class brings together words describing the perception on the precarious structure of health services that aggregate care in AHR, since the participants of this group know this reality closely. In the organizational context of health services in AHR, accessibility, the perceived differences between public and private services, and the ethical issues involved in the topic have emerged.

When analyzing some typical words of this class, such as "expensive", "condition", "access", "service" and "difficult", one could observe the sixteen participants highlighted the issue of unequal access to services providing reproductive technologies.

It's only for those who can pay, those who cannot have no access to it. Because in private institutions there is no coverage, so only those with resources and money can go to a place like this. (P.F.2)

Everything is very expensive. It's a very closed thing, it's for the few. Unfortunately is not something for the poor, it can't be, there is no way, everything is so very expensive. (P.M.12)

Faced with the difficulty of access, mainly due to the financial factor, all the participants pointed out the difference of assistance between public and private services offering reproductive biotechnologies.

Assisted human reproduction is not disclosed in the public service, besides having no incentive, there is nomoney to cover this part. (P.M.12)

The public service still has a lot to grow, it is crawling on assisted reproduction, it has no government incentive, the specialists are working in their private clinics but not in the public service. (P.F.16)

Ethics was something that concerned thirteen participants, especially regarding institutional, professional, and individual issues related to the reproductive limits involved in AHR.

Some places are money factories. I'm worried because it is too much money, it is a market actually, and sometimes without any ethics. You cannot have services and professionals aimed only at profiting. And this makes people grow distrustful of the assisted reproduction, thinking it's only a business. (P.F.6)

Some have been using assisted human reproduction in a wrong, unethical manner. It's a good thing that came to add up and help in the treatment of those who have difficulty having children, but in the wrong hands can become something dangerous, so we need a legislation and supervision. (P.F.14)

To work in assisted reproduction, the ethical issue is worrisome, mainly because we deal with intimate and delicate situations of people. We deal with sexuality, with the body, with the limits of reproduction, so, above all, we need to be very ethical professionals. (P.F.13)

\section{Class 6: Assignments of nursing practice/care in assisted human reproduction, anchored between technology and humanization}

Class 6 was structured with 41 UEC, representing $8 \%$ of the corpus. The analysis of the lexical universe printed the attribution of the nursing practice/care on assisted reproduction. Regarding the participants' discourses concerning their perception of nursing care in AHR, the words "care", "different", "humanization", "quality", "accompany", "explain", "welcome" and "technology" illustrate 
the practical dimension of nursing care within the scope of the interpersonal relationship subjectivity between professional and clientele, while pointing out the involvement with technology.

The nurse must provide care with a lot of patience and respect to the couple. The nurses' performance must be based on humanization due to difficulty of assisted reproduction, but they must also know the whole technological process. Caring for these couples is very difficult and laborious because doing this kind of treatment requires a lot of perseverance, dedication and patience. We have to know each case, to follow them up 24 hours a day, total dedication, because our failure can destroy their dream [of having a] child. (P.F.4)

The nurses' reception is fundamental in a assisted human reproduction full of high technology. The nurse is the flagship, because it is they who accompanies the whole process, all the treatment depends on them, on their understanding of each step... Such performance always face the unforeseen and the intercurrences. (P.F.7)

The nurses' performance, in the perspective of care subjectivity, requires a technical-scientific basis, and its practice must be based on scientificity, mainly because it is a highly technological context.

\begin{abstract}
After the exams and diagnosis, the antagonist or agonist protocols pass through me. I explain the whole protocol. Patients over forty, with low ovarian reserve, use agonist protocol, which improves ovarian stimulation. Antagonist protocol for patients with good or medium follicular reserve. I'm the one who controls and monitors everything, so I need to have a lot of scientific knowledge about physiology, anatomy, endocrinology, and a lot of attention. (P.F.6)

We have to do our job very well, as any mistake can lead to failure. With all technology, everything should be based on scientific knowledge and not guesswork. There are nursing processes within the assisted reproduction that are not equal to any other, they are very specific, encompassing consultation, prognosis, a complex and individualized nursing process. (P.M.15)
\end{abstract}

\section{DISCUSSION}

The scarce supply of academic instrumentalization in the AHR segment generated worries and concerns for the nurses participating in this research. This issue was represented as an academic institutional helplessness, signaling the lack of assistance models and nursing specialists in the area. The AHR has elements that challenge the human and professional potential regarding knowledge, which requires a deepening of science, to contemplate the lack of scientific information in the academies in their different prisms ${ }^{(13)}$.

Considering social representation as a preparer for action, a guide to behaviors, it is possible to understand that the fragility of knowledge of the professionals involved justifies the attitude of the search for new strategies to broaden and sustain the practice through related personal alternatives, such as the internet, books, articles, and thematic discussions in daily life ${ }^{(8)}$.

Results of this research indicate the elements that characterize the informative dimension about AHR since they demonstrate the organization and the search for knowledge of the researched group regarding this social object. This dimension is responsible for revealing the intricacies of AHR face the timely and evident proximity that exists between the researched object and the study participants. Such proximity reveals a relevant factor in social representations, where the sources of information are places of mediation of various types of communications, being, at the same time, the starting point of information and a support for communication ${ }^{(8)}$

However, participants emphasize that all means they use to acquire information comes from a personal/individual demand, resenting the lack of a more formal and academic knowledge. The absence of reference for nurses working with AHR becomes de-structuring from the point of view of the constitution of the area and the professional habit.

At the same time, this thought attributed to AHR performance favors the creation of the thinking of the figure-type nurse working in this area. This type-figure would be one that, in assembling a set of characteristics identified by the group, would be assuming the social identity that can serve the purposes of each segment ${ }^{(14)}$. The constitution of this figure emerges as a resource that authorizes or not the nurse to act in AHR.

In this perspective, the characteristics of nurses working with AHR are initially those inherent to a professional qualified to work in any field of nursing - emphasis given to commitment, involvement and responsibility. However, they recognize some essential attributes for the nurse to be qualified in this specific area of sexual and reproductive health.

The need to seek knowledge in technology to subsidize their actions, full dedication to this new theme, ethics in dealing with such intimate issues of the couple/individual, and careful listening coupled with reception are mandatory characteristics for nurses working with reproductive biotechnologies. These elements that are connected in forming the image of this nurse are anchored, mainly, in the representation of the "good" professional strereotype ${ }^{(15)}$.

The construction of meanings, symbols, and norms referring to a nurse working with AHR is based on the group's identity, described as that competent professional to deal with something new and challenging. This process of construction leads individuals to organize representations that are products of their own subjectivity, involving experiences, traditions, and influences of their social environment ${ }^{(9)}$. In this thinking, the play of emotions, affections, feelings, imaginary, and factors is the element that nourishes the construction of these nurses' social representations.

The performance in a new field seems to have aroused the interest of these professionals by this specific area. Such rationalization gives a precise and objective explanation to their feelings and emotions, understanding that these technologies symbolize the path and the solution, especially for couples/individuals with reproductive problems. This situation is also justified by considering that nurses working in AHR are motivated by these novelties and are self-represented as differentiated professionals. Working with motivation allows for qualified assistance that can result in therapeutic success, since motivation is an essential stimulus of the affective dimension that seems important in characterizing the type-figure of these nurses ${ }^{(14)}$.

In this context, working in this area implies choices mediated by affections, i.e., in order to assist well, one must be considerate, welcoming, committed, involved and, above all, one must like to work in assisted human reproduction. 
Regarding the structure of health services that include AHR care, the results showed the research participants understand its precariousness, considering the differentiated accessibility for the assisted clientele and the low attention to the most vulnerable and low purchasing power population.

Participants considered that reproductive health for conceptive purposes is a type of care whose access is only allowed to those who have financial conditions, and it is not a constitutional right that should be experienced and accessible to the population.

Concerning difficulties of access to services and goods related to $A H R$, the participants expose the intimate relationship of reproductive biotechnologies with market demands, as a current desire for consumption ${ }^{(16)}$. The search for these technologies has increased, even in more economically disadvantaged layers; however, because it is still a high-cost service, it ends up limiting the admission of those who need this type of assistance ${ }^{(16)}$. The issue of unequal access and the difficulties faced by potential candidates for reproductive techniques reveal the vulnerabilities the couple/individual faces when seeking to achieve the dream and project of a biological child ${ }^{(17)}$.

The problem of AHR non-implementation in public services is due to a lack of government commitment to the specific population, as it does not invest financial resources and does not train health professionals in the area, as recommended by the guidelines of the National Policy for Comprehensive Care in Assisted Human Reproduction (Ordinance No. 426/GM, dated March 22, 2005(18), and No. 3,149, DATEDDecember 28, $\left.2012^{(19)}\right)$.

To transform the unfamiliar or unknown object into something familiar, the participants objected to the unscrupulous professionals working in AHR as "wrong hands", which leaves users of this service in conditions vulnerable to misconduct and unethical behavior.

Another concern relates to the involvement of AHR care with the private health care system that is imposed by profitable marketing rules, running the risk that the ethical issues of assisted procreation are left in the background. In addressing ethical concerns, they perceive the frailties to which the couple/ individual is subject in the complex and implicit relationships between desires, dreams, and the financial market ${ }^{(20)}$. The lack of inspection of AHR services leads to a market situation that does not contemplate the ethical issues inherent to human reproduction, a fact that generates negative representations about this type of reproduction in society, lasting in the social memory.

The advent of reproductive technologies brought disruptions to the representations, beliefs and values about life that until then were considered as certain and untouchable, especially when referring to ethical and religious issues ${ }^{(21)}$. All scientific knowledge and lay thinking does not emerge from an emptiness but is elaborated and fed on previous knowledge and ideas, as well as collective memories ${ }^{(8)}$.

The practical dimension of social representations emerged from a real daily routine lived by the participants in a new work area enriched by dilemmas, mainly ethical, that demands positioning and attitude from these professionals. In this perspective, the practical dimension of customer care has been reinforced as a performance different from any other nursing activity, as it is based on reproductive technologies and because this professional is responsible for monitoring the stages of the biotechnology process, which requires technical and specific knowledge on the entire AHR procedure, individualizing each case, representing themselves as technical professionals, albeit also humanized and sensitive to the stories of couples/individuals.

The possibility of fulfilling this reproductive expectation that disturbs the natural representation of human reproduction is emphasized since it mobilizes internal and external tensions as to the need to give meaning to ties and relationships, even if it implies the natural or cultural dimension of the complex family dynamics.

Results reveal the subjective expression of nursing care to the couple/individual who seeks specialized AHR care. For these professionals, providing care to this clientele, even in a highly technological environment, means using a non-verbal language of empathy, hope, trust, and respect for their biopsychosocial demands. These processes of nursing know-how must consider subjective factors such as the experiences of the professional, as well as the historical-cultural context in which they are inserted.

In addition to this affective and subjective dimension of care, the participants characterized the AHR nurse as the professional "flagship" of reproductive care, translating into an iconic quality of an idea and producing a new image ${ }^{(8)}$. Even though they are not the professional who performs clinical and drug indications or manipulates laboratory technologies, this characterization is due to the understanding that it is the nurse who first welcomes and follows the physical and psychological evolution of the couple/ individual. They also take care of, humanize, advise, explain, apply medications, verify their effects and become available to the clientele for extended times and days, promoting quality health care.

This group of belonging, here represented by nurses who work directly with AHR, defines the conditions of representativeness of these professionals' knowledge about reproductive biotechnologies, considering that knowledge about something also represents the people who own and use them ${ }^{(7)}$. This representation of the nursing care intersubjectivity in AHR finds support in the figure-type, as evidenced in class 1.

Nurses have in the work environment an element of the construction of their social representations about their performance, as these are not engendered in individuality but in a social context that takes part in the training process ${ }^{(9)}$. In this perspective, the workplace is where ideas and information about reproduction and biotechnologies emerge and circulate, in addition to being where interactions occur with couple/individuals and other health professionals.

\section{Study limitation}

The research is limited by the restriction of study universe and location to the city of Rio de Janeiro. In this perspective, further research is required in different regions, aiming to broaden the discussion and provide knowledge about the relationship between nurses' performance in AHR and advances in reproductive biotechnologies in the care of couples/individuals.

\section{Contributions of the study}

The discussion on the subject of AHR in the area of nursing is essential, considering the need to disseminate the nurse's role in 
the specificity of the reproductive health care of couples/individuals who seek this type of assistance and regarding the scarcity of health care services to meet a greater demand related to the sexual and reproductive rights of the Brazilian population, as well as the challenges to be faced regarding the new ethical paradigms in the work scenario of the nurse as a member of the health team.

\section{FINAL CONSIDERATIONS}

Immersed in the subjectivity of nurses working in the area of sexual and reproductive health, and in the light of social representations, we understood the discourse about a phenomenon that has been transforming - or even destabilizing - old representations that were regarded as untouchable, as is the case of human reproduction. This research made it possible to translate the constitutive elements of these professionals' representations about the nurses' performance in AHR and to know where these representations are anchored, revealing the practice before this new reproductive approach.

We concluded the participants' social representation about the nursing work in AHR is based on the link between technology/ medicalization and humanization/reception in relation to reproductive biotechnologies. Working in the AHR involves a new and challenging nursing care; in their representation, the nurses considered themselves pioneers in this type of sexual and reproductive health care, trained in the work routine and in the constant search for updated knowledge based on scientific evidence, as a means to supply the academic lack of information.

It stands out this is a lay thought, socially constructed, that needs to be interpreted in scientific bases, with as such as more subsidies in the elaboration of specific programs and policies in the field of sexual and reproductive health. One can see that reproductive-related public policies, in spite of the legal directives of the National Policy on Comprehensive Care in Assisted Human Reproduction, have proved to be ineffective and incapable of reducing access inequalities to meet the reproductive demands of current couples/individuals, preventing them from exercising their reproductive rights. Finally, in the search for a solution, the clientele remains vulnerable to the logic of private health and lack of financial resources, which promotes inequalities of access and difficulties faced to achieve the dream and desire of a biological child.

\section{REFERENCES}

1. Corrêa MCD, Loyola MA. Assisted reproductive technologies in Brazil: options to improve access. Physis [Internet]. 2015 [cited 2017 Oct 5];25(3):753-77. Available from: http://www.scielo.br/pdf/physis/v25n3/0103-7331-physis-25-03-00753.pdf

2. Choudhary KK, Kavya KM, Jerome A, Sharma RK. Advances in reproductive biotechnologies. Vet World [Internet]. 2016 [cited 2019 Feb 1];9(4):388-95. Available from: https://www.ncbi.nlm.nih.gov/pmc/articles/PMC4864481/pdf/VetWorld-9-388.pdf

3. Silva EFG, Barreto C. Homens que vivenciam a infertilidade: clientes da "cegonha tecnológica". Rev Abordagem Gestalt [Internet]. 2017 [cited 2017 Oct 7];23(1):10-21. Available from: http://pepsic.bvsalud.org/pdf/rag/v23n1/v23n1a03.pdf

4. Félis KC, Almeida RJ. Perspectiva de casais em relação à infertilidade e reprodução assistida: uma revisão sistemática. Reprod Clim [Internet]. 2016 [cited 2017 Oct 7];31(2):105-11. Available from: https://enfermagem.sbrh.org.br/wp-content/uploads/2017/09/pesrpectivas.pdf

5. Souza ER, Monteiro MAS. Repensando o corpo biotecnológico: questões sobre arte, saúde e vida social. Teor Soc [Internet]. 2015 [cited 2017 Oct 11];Spec No:159-71. Available from: http://teoriaesociedade.fafich.ufmg.br/index.php/rts/article/view/114/91

6. Pereira MS. Lei do exercício profissional de enfermagem e a autonomia profissional do enfermeiro. Enferm Foco [Internet]. 2013 [cited 2017 Oct 13];4(3,4):171-4. Available from: http://revista.cofen.gov.br/index.php/enfermagem/article/download/543/226

7. Jovchelovitch S. Vivendo a vida com os outros: intersubjetividade, espaço público e representações sociais. In: Guareschi P, Jovchelovitch S, organizadores. Textos em representações sociais. 14ª ed. Petrópolis: Vozes; 2013. p. 53-72.

8. Moscovici S. Psychoanalysis, its image and its audience. Petrópolis: Vozes; 2012.

9. Jodelet D. Ponto de vista: sobre o movimento das representações sociais na comunidade científica brasileira. Temas Psicol [Internet]. 2011 [cited 2018 Oct 5];19(1):19-26. Available from: http://pepsic.bvsalud.org/scielo.php?script=sci_arttext\&pid=S1413-389X2011000100003\&lng=pt

10. Brasil. Conselho Nacional de Saúde. Resolução CNS n 466, de 12 de dezembro de 2012. Aprova diretrizes e normas regulamentadoras de pesquisas envolvendo seres humanos. Diário Oficial da União. 2013 June 13.

11. Appolinário F. Metodologia da ciência: filosofia e prática da pesquisa. 2a ed. São Paulo: Cengage Learning; 2012.

12. Azevedo DM, Costa RKS, Miranda FAN. Uso do Alceste na análise de dados qualitativos: contribuições na pesquisa em enfermagem. Ref Enferm UFPE [Internet]. 2013 [cited 2017 Oct 14];7(Suppl 7):5015-22. Available from: http://www.revista.ufpe.br/revistaenfermagem/index. php/revista/article/view/3297/pdf_3090

13. Jafarzadeh-Kenarsari F, Ghahir A, Zargham BA, Habibi M, Hashemi M. Patient-centered fertility care: from theory to practice. J Midwifery Reprod Health [Internet]. 2016 [cited 2018 Oct 5];4(3):712-9. Available from: https://jmrh.mums.ac.ir/article_7186_0614e1963c68a35571e42 2a9578dd57a.pdf

14. Rodrigues ILA, Motta MCS, Ferreira MA. Social representations of nurses on tuberculosis. Rev Bras Enferm [Internet]. 2016 [cited 2017 Oct 17];69(3):532-7. Available from: http://www.scielo.br/pdf/reben/v69n3/0034-7167-reben-69-03-0532.pdf

15. Maynart WH, Albuquerque MCS, Brêda MZ, Jorge JS. Qualified listening and embracement in psychosocial care. Acta Paul Enferm [Internet]. 
2014 [cited 2017 Oct 17];27(4):300-4. Available from: http://www.scielo.br/pdf/ape/v27n4/en_1982-0194-ape-027-004-0300.pdf

16. Garcia S, Belmy M. Assisted conception services and regulation within the Brazilian context. JBRA Assist Reprod [Internet]. 2015 [cited 2017 Oct 17];19(4):198-203. Available from: https://www.researchgate.net/ publication/284195126_Assisted_Conception_Services_and_Regulation_within_the_Brazilian_Context

17. Inhorn MC, Patrizio P. Infertility around the globe: new thinking on gender, reproductive technologies and global movements in the $21 \mathrm{st}$ century. Hum Reprod [Internet]. 2015 [cited 2018 Oct 5];21(4):411-26. Available from: http://fertility.com.br/wp-content/uploads/2017/02/ reuniao-maio-17-edson03.pdf

18. Ministério da Saúde (BR). Portaria n 426/GM, de 22 de março de 2005. Institui, no âmbito do SUS, a Política Nacional de Atenção Integral em Reprodução Humana Assistida e dá outras providências. Diário Oficial da União. 2005 Mar 22;(56):22. Seção 1.

19. Ministério da Saúde (BR). Portaria $n^{\circ}$ 3.149, de 28 de dezembro de 2012. Ficam destinados recursos financeiros aos estabelecimentos de saúde que realizam procedimentos de atenção à Reprodução Humana Assistida, no âmbito do SUS, incluindo fertilização in vitro e/ou injeção intracitoplasmática de espermatozoides. Diário Oficial da União. 2012 Dec 31;(251):232. Seção 1.

20. Alves AMAL, Oliveira CC. Reprodução medicamente assistida: questões bioéticas. Rev Bioét [Internet]. 2014 [cited 2017 Oct 17];22(1):66-75. Available from: http://www.scielo.br/pdf/bioet/v22n1/a08v22n1.pdf

21. Batista LAT, Bretonesa WH, Almeida RJ. O impacto da infertilidade: narrativas de mulheres com sucessivas negativas pelo tratamento de reprodução assistida. Reprod Clim [Internet]. 2016 [cited 2017 Oct 17];31(3):121-7. Available from: https://www.researchgate.net/publication/305385058_O_ impacto_da_infertilidade_narrativas_de_mulheres_com_sucessivas_negativas_pelo_tratamento_de_reproducao_assistida 